\title{
THE THEMES OF GLOBAL DEVELOPMENT AS A CHALLENGE FOR CONTEMPORARY EDUCATION IN THE REFLECTION OF FUTURE TEACHERS
}

The themes of global development should form a significant part of the educational process and also of the so-called turning-to-the child education. The themes include the consequences of globalization, technological development, and the lack of ethical reflection connected with them. The article is divided into a theoretical and an empirical part. The theoretical part is focused on the explanation of the terms still not widely known in the educational process: global citizenship and responsibility, the limits and borders of global development in education, and the way of passing along ambiguous themes. The empirical part presents a concrete lesson on the theme of food waste in the fifth grade of a primary school and its analysis by future teachers, the students of the Faculty of Education at Charles University. The paper is mainly focused on the points which the future teachers considered to be important and which they neglected or "were not able to see."

Keywords: themes of global development, ethical challenges, global citizenship, food waste, fifth grade of a primary school, future teachers, transcendence, turning-to-child education

\section{Theoretical challenges for global development education}

A rising number of teachers in the Czech Republic deal with how to teach global development themes. Why are they so important? How are we to work with them in the classroom? These are the questions that dissuade many teachers from teaching them. These topics are the result of processes that have been taking place in society for many years. It is the process of globalization, technological development, but also the absence of the reflection of ethical issues which are implicit in them and which are not deemed important by many, despite the fact that they (the topics of global development education) entail the "general value systems" of man [1, p. 36].

\subsection{Human responsibility for the world is a part of turning-toward-the child education}

Czech philosopher of education, N. Pelcova, says that education is still under the influence of subject-object thinking. In practice, this is reflected in the fact that "all that is living is degraded to the status of a mere object"; in people's minds, nature can then be "conceived of only as a raw material resource, [it is perceived that] man [can be] used as a means of achieving another goal” [2, p. 35; p. 5]. As the philosopher M. Buber said, the other person is not You, but It. I can use It to my advantage, regardless of the consequences of my actions. The result of human progress is the fact that most people in the so-called Western society have plenty of food, medical care, and technical facilities. Progress and a personalized and individualized way of life [3] have influenced the relationships of man to the whole. Responsibilities for the whole world have disappeared from everyday life, but also from the school curriculum [4]. Man has ceased to be an "authentic being" who seeks to overcome himself [5, p. 155].

As early as the late 1970s, the German-born Jewish philosopher H. Jonas spoke of new challenges for society. One of these challenges was, "Act in a way, so that the effects of your actions will not destroy the future of such a life" [6, p. 35]. H. Jonas is primarily concerned about acting responsibly towards the whole. This includes two possible understandings of the notion of responsibility. The first is "responsibility as a causal attribution of executed acts". Only after a person has acted in a concrete way is he responsible for the consequences of his actions. It follows that the less one acts, the less he is responsible ("the lass man acted, the less he has to account for"). The second type of responsibility is related to the future. It is the responsibility "for what needs to be done". H. Jonas explains this second type of responsibility as

\footnotetext{
* Noemi Bravena, Jana Stara

Catholic and Hussite Theological Faculty, Faculty of Education, Charles University, Prague, Czech Republik

E-mail: noemi.bravena@centrum.cz
} 
follows: this responsibility arises before man everywhere where the concern is "well-being, interest or the fate of others" who have "because of the circumstances or based upon an agreement got under my protection, which means that my control over them at the same time includes my duty towards them" [7, p. 143-144]. The problem of today's society is that it does not feel responsible for its future. Another characteristic of such responsibility is, according to the author, "continuity". The responsible parent and the statesman always have to keep asking, "What will happen then?", "Where will it go?" and at the same time: "What preceded this?" According to H. Jonas, man is to be responsible for what transcends him time-wise, "What is that concerning which the responsible person can no longer be ultimately responsible". [8, p. 162-163]. This is perhaps the reason why this characteristic of responsibility is not spoken about often.

Pedagogy has underestimated the transcendence of man. Turning-to-the-Child defined by the Czech pedagogical psychologist Z. Helus encourages the development of the child's entire personality, i.e. one's ability to transcend oneself. Although this new Czech term can be correctly associated with the concept of child-centered-education, it is used for the new paradigm in the Czech education known as child-centered-education of the new generation (Z. Helus, V. Spilkova). The main task is to liberate a man from his everyday routine and to guide him to four types of teaching goals: "anthropological", "ethical", "contextual" and "transcendental" [9, p. 5-6]. The turning-to-child education objectives also include "overlap objectives (transcending)", which emphasize "respecting binding values beyond the individualistic life balance: respecting the values of truth, goodness, beauty, interpersonal solidarity, etc.” [10, p. 30]. Responsibility for what transcends man time-wise belongs to this new concept of teaching. This can have a positive effect on the personality of the pupil and it is, therefore, a certain prevention against the negatives of a world influenced by technology.

\subsection{Responsibility and the framework educational program for elementary education}

In the Czech curriculum document, Framework of Educational Programs for Basic Education (FEP BE), is "competence to solve problems". One of the definitions is that the pupil "thinks critically, makes judicious decisions, is able to defend them, realizes responsibility for his decisions, and evaluates the results of his actions". In this formulation, the notion of decision is linked to a specific content - with "problem-solving" and "outcomes of the action". This would mean that responsibility is only the result of a specific decision or action (H. Jonas's first type of responsibility) [11].

Most concerned with the concept of responsibility is the subject of Ethical Education. However, it is only an optional part of the school educational program in the Czech Republic. In some educational areas, this term is present, but it does not stand for a comprehensive concept of responsibility. In the primary (ISCED 1) school, the notion of responsibility can be found in the teaching field called Man and His World ("considerate behavior towards nature, nature conservation - people's responsibility, protection and formation of the environment, protection of plants and animals") [12, p. 33]. The theme of general responsibility also appears in cross-curricular themes. A concrete example of this is the topic "Education of a Democratic Citizen", in which the pupil is led to the fact that "participation in the decisions of the whole is connected with the awareness of one's own responsibility for these decisions and their consequences." We also find the concept of responsibility in the following cross-curricular themes: "Education for Thinking in European and Global Contexts", "Multicultural Education", "Environmental Education", and "Media Education" [13].

We see that the notion of responsibility is not an insignificant part of the Czech curriculum, although it could be more frequent in compulsory education areas. It can be assumed that in the learning process, the concept of responsibility is approached rather in an applied manner. And here is perhaps one of the answers why the themes of global development education, which very strongly emphasize the second type of responsibility (according to Hans Jonas), are difficult for many teachers.

\subsection{Responsibility and global citizenship}

Man is a part of the world globalization process that cannot be stopped. Globalization "brings new problems which are the natural consequences of the speed and the urgency of the necessary changes" [14, p. 262].

A global citizen is one who: Is aware of the wider world and has a sense of their own role as a world citizen. Respects and values diversity. Has an understanding of how the world works. Is passionately committed to social justice. Participates in the community at a range of levels, from the local to the global. Works with others to make the world a more equitable and sustainable place. Takes responsibility for their actions" [ 15 , p. 5]. In theory, everyone becomes a global citizen by their birth, but they really become one only through an internal identification with such citizenship and a conscious commitment to it. Like any nationality, it can be defined locally, historically, culturally and socially, but in a different way than conventional nationality. The fellow-citizenship includes the entire planet (animate and inanimate nature), that which is close, but also that which is totally alien to the given man [16].

Despite the ambiguity, the notion of global citizenship is linked to the concept of global ethics [17] and with certain actions considered to be moral by the majority of society. Even though the term global citizenship is more challenging for the teachers and tends to lead to ambiguity, its appeal is clear - to lead pupils 
to embrace responsibility for the world. What is the practice of education for global citizenship and where are the current open challenges for which teachers need to learn to seek answers? We will see this on a concrete empirical survey and its analysis.

\section{Qualitative research methodology}

\subsection{Contemporaneity of the topics of education for global citizenship}

Education for global citizenship is presently changing and developing. This results in an increased need to equip (future) teachers with the appropriate knowledge and skills to implement such training in practice [18]. The research of attitudes towards education for global citizenship among pedagogy students [19] has shown, that students perceive the area of education for global citizenship as very important, but do not feel too competent to engage in school projects dealing with certain aspects of global citizenship. The reason may be the complexity of this educational area and the need to deal with controversial issues. This could also be connected with the fact that "the professional development of teachers in the Czech Republic is unsystematic" [20, p. 133].

\subsection{Research objectives and research questions}

Our study focused on the reflection of important phenomena in a lesson of Education for Global Citizenship [21] by future primary school teachers, students of the faculty of education. The general objective of the research was to describe and explain what future teachers are observing and noticing in a lesson at the 5 th year of primary school focused on education for global citizenship.

The research question has been formulated: How do students of pedagogy reflect the content and process of teaching focused on the topic of education for global citizenship? This question was then divided into two specific research questions:

1. What content are they noticing and reflecting in the class?

2. Which educational methods and practices do they notice and reflect upon?

\subsection{Research methods and data collection}

A qualitative analysis of student reflections was chosen as the research method. Data collection took place in June 2015. We asked students to watch a video of a whole Czech social studies lesson at a primary school (Grade 5). The lesson is a separate content unit, and for understanding it, it is not necessary to know the context in which it is set. The students were asked to write what they "considered important and noteworthy" about the monitored lesson. They were told that there "were no correct or wrong answers" and that they should "feel free to write their honest views". The majority of students were in their mid-twenties and had teaching experience only within a compulsory practice, which includes an average of 12 lessons of different subjects. These students have taught lessons of social studies only once to three times [22]. These data were also analyzed in a quantitative research of the knowledge-based reasoning of future teachers of different subjects [23].

\subsection{Description of the monitored and reflected lesson by future teachers}

The lesson was about mediating issues of wasting food. The lesson began with brainstorming about what food waste was. The teacher then projected a graph showing the differences in the amount of food waste in Asia and North America on the interactive whiteboard for the pupils to see. Then the pupils in the groups drew an outline of a fruit tree on a paper. They were supposed to write about the causes of food waste into the roots, the ramifications of this waste to the branches, and the ways of solving the problem into the root. They presented their work, the others evaluated it, and they then expressed their opinion about the evaluation. The teacher projected expert suggestions on tackling food waste issues on the interactive whiteboard. The teacher invited the pupils to compare their suggestions for solutions and these suggestions by the experts. The teacher announced that the pupils would be involved in a campaign to alert other pupils at the school about the issue of food waste. At the end of the lesson, the teacher and the pupils summed up the issue.

\subsection{Research participants selection}

Research participants were students of pedagogy for the primary school on the Faculty of Education at Charles University. When they finished their social studies of didactics (in 4th grade of their five-year master study), a group of them was asked to watch a video of the lesson and write a reflection. Of the total number of 69 students in that year, the study was conducted by 23 students (only women). J. Stara taught this group of students an optional course, so it was a sample of respondents that was available.

\subsection{Data analysis}

First of all, we identified the meaning units in the data obtained from student essays and we subsequently named the codes. The first codes were allocated $a d$ hoc, and then the codes 
were renamed, refined, merged, etc. Continuous hierarchization of codes created more general categories. In the next phase, issues that were found to be crucial in coding were compared with video from the class.

\section{Results of research and their importance for teachers}

The results of the research are presented in a way that summarizes the problem of the lesson at primary school, followed by the students' response to this problem, and then briefly summarizing the meaning for the teacher.

\subsection{Stereotypical thinking}

There are stereotyping statements in the monitored primary school lesson, such as: Children in Africa would be grateful for your snack; He throws away an apple instead of giving it to someone in Africa. Because the American is not grateful for how he is doing, he always drinks Coca Cola and eats hamburgers. The teacher did not respond to them, with only one exception.

A majority of the students from our sample did not notice that pupils manifest this stereotyped thinking during the lesson. Only 4 students noticed (described the situation) the phenomenon (the presence of stereotypical statements). However, no comment related to this phenomenon contained any reference to theory, nor was there a technical term used in the student reflections (stereotypes, stereotyping, ...).

The question we have to ask is this: Why do teachers not respond to stereotypical statements or do not consider them important? When a small child does not want to eat, its mother says: If a child in Africa had your food, he would eat it. A little child at that time does not even know that Africa exists and cannot imagine real hunger at all. But because of this parental reaction, it learns that if we behave badly to food, "a child from Africa" appears. The stereotypes are so deep within us that our proneness to stereotypes is, in fact, unconscious. It is not about completely eliminating stereotypes (it is not even possible), but the teacher should be aware that it is possible to work with them, so that the pupils learn to find them and realize their meaning. Many of these stereotypical statements flatten the real problems in society and lead pupils to apathy and inactivity [24].

\subsection{Relationship between the subject and real life (authentic learning)}

Many students were aware of the importance of the relationship between the subject and the real life. In their reflections, however, they do not use the term of authentic learning or the terms constructivism, preconceptions, etc. but they adequately describe the phenomenon or use the phrase linking life with school or pupil experience.

\subsubsection{The learning task of the tree}

In the lesson, the pupils solved the learning task of the tree (see above).

According to the students, this learning task is important because it allows the pupils to work with their own experience: Using the tree and its parts (roots) helps the children to imagine the specific dimensions of the problem better. In addition, the pupils can work with their own life experiences and communicate their experience in the group work. The learning task leads to learning outcomes linked to the pupils' lives (including attitude change): Finding problems is very important in this assignment and it plays a big role in pupils' lives.

None of the students noticed that the tree parallel basically breaks the whole of the lesson into three distinct entities: causes of waste, consequences of waste and solutions - the teacher works on the individual parts of the tree, i.e. solves all the causes, then all the consequences and, in a moment, all the solutions proposed by the children. The problem is that taxonomic lists of causes and consequences weaken the most important reality - the problem of wasting food as a complex human problem. If we watch children working in a group, we see something unique. The children consider the topic as a whole, i.e. they connect specific causes, consequences and solutions. There is no such complex thinking of children when presenting a topic together in the classroom. This is why there were at least two misunderstandings between the pupils - they give each other "minus points" or question marks for information that they disagree with or are not able to understand. This teaching style results in the fact that the child does not learn, for example, that one solution has more causes or that similar situations require different solutions. The pupils are also not lead in terms of situational ethics to distinguish similar situations with different solutions.

\subsubsection{Method selection as a topic for gde (global development education)}

The teacher works with pupils using multiple methods.

According to the students, the methods used (brainstorming, group problem analysis (tree), presentation) bring the pupils "into" the problem (motivate the pupils): In the group work, however, it can be seen that pupils are already trying to tackle the problem, they are discussing.

The students did not notice that the pupils worked in a group with their own experiences, but what they were writing into the tree were words selected beforehand. Therefore, important statements relating to the anthropological factors of the problem 
of food waste remained unnoticed. This is, for example, the case of a girl's statement: "The rich do not see a problem in this"; or a boy's: "We do not realize this". The children themselves perceive the anthropological depth of the problem of food waste, which is not further reflected in the lesson. The teacher should have rather included a group dialogue with the children or other work with the tree. Some groups of the children could have examined only one part of the tree in detail, others could have worked with the tree as a whole and thus present it to others. It was clear that in order to develop the moral competence of man in GDE, the choice of methods is very important.

The students wrote that it is a necessary prerequisite for affective learning for pupils themselves to adopt an affective goal [25]. By the right choice of teaching methods, the teacher could have influenced the emotions of the pupils [26]. The students criticized the fact that the pupils were not led by the teacher to change their attitudes: Children (had the teacher been more convincing and used other methods) would have found out that this problem is also their problem, that they too must fight to improve the situation. By talking in a third person, it seems to me that they feel like this does not really concern them...

There remains an unanswered question from the students' reflections: How do the students imagine working with emotions? Here, a short movie or a dramatization proves to be an excellent didactic element.

\subsubsection{Teacher as a model and facilitator}

In the lesson record, we see that the teacher accompanies the pupils in the subject. How did the students perceive the teacher as a model?

For students, the teacher was not a convincing example of a person who treats food economically and is engaged: Yes, he tells the children that food should not be wasted, but I myself felt that even he would throw the unfinished apple away. It also seemed to me that he did not go to the heart of the point with the children. He does not ask any further. He does not try to get the kids to really think about the problem. One pupil answered that people were wasting food because they would never run out of food. This is, in my opinion, an interesting idea! However, the teacher passed over it and did not work with it any further. It was excellent that some children are able to see the problem in a broader context. For example, the answer that the result of wasting food is also the destruction of nature, due to the constant transport of more and more food, was great. One could also work further with it.

From an analysis of the lesson, students base their feedback on the certain impressions the teacher gave them. In some of the teacher's reactions, we, unfortunately, see that he does not want to go deeper into certain topics (food in the school canteen, etc.) and this weakens his authority.

\subsubsection{Student experiences and their problem solving}

According to the students, the teacher does not take sufficient account of pupils' experiences, ideas, thoughts: Certain pupils' answers were not bad at all: "Many people in school canteens do not finish eating the meal and they throw it away." The teacher disregards this idea by saying that "The school canteen is a hot topic, so I would focus on that". Still, the pupil does not attack the school canteen, so I would appreciate this answer. The children encountered food every day in the school canteen and it really is wasting when they return food. What could be done with it? What about asking the cooks for smaller portions? Or unregister for the specific lunch when I know that I do not like the given meal?

Students correctly described that the teacher has to bring depth into everyday topics because only this leads the pupil to a deeper understanding of responsible behavior. The problem of the given school canteen is not only ethical but also legislative. The pupils repeatedly mentioned during the lesson that they would give food to those who needed it. This officially cannot be done in the school canteen. The teacher does not lead to this differentiation in the lesson: good solution and feasible - good solution, but it is not feasible in the context of the society's laws.

\subsubsection{Moralizing}

The students noticed that the teacher moralizes: He then added his example of the fruit pupils receive at school and reminded them that they are often wasteful with it. Here, I would rather choose a question to make the pupils realize it themselves. This statement seemed very moralizing to me.

It would be a mistake if the teacher did not react in such a situation at all. Students, however, grasped one important fact, namely that such reaction of the teacher will rather discourage the pupil from responsible behavior. The teacher could have asked the children for example "What leads the children to their wasting of food?" and then further discuss this problem with them.

\subsubsection{The formal approach of the teacher}

Two students have criticized the teacher's formal approach: In this answer, I personally see great truth and depth, so I was sorry that the teacher had not worked with this sentence further at all. At the same time, I noticed that children speak very broadly, generally, relating everything to humanity at large, "we as people are too picky, we do not want something for a snack, so we throw it away, etc." I liked how the teacher turned Max's question towards the pupil himself. I would do it the same way with everyone else. The children would then come to realize that this problem is also their problem that they too must fight to improve the situation. By talking in the 
third person, it seems to me that they feel that this does not concern them much. The students suggest using the student responses and the children's ideas more: I felt it was a shame that the teacher did not work with these pupils' ideas, and he did not ask what they all meant by them, where these things then play out. How it works, how it does not work. Why it could or could not be that way. It seemed to me that he was trying to stick to the lesson plan, but did not really reflect what the children were saying and did not discuss it with them ...

It is clear from the student responses that topics of education for global citizenship require greater teacher engagement, a willingness to do things differently, a willingness to ask children more and to develop their opinions, and to discuss with them more.

\subsection{Content specifics of the subject of food waste}

The teacher focused on the topics of the tree: causes, consequences and solutions. But that is not the only content of the subject of food waste. Some of the students have expressed the importance of leading children to active involvement. In addition to the aforementioned comments related to the education of indifferent individuals willing to behave responsibly, we expected the students to comment on the school campaign mentioned by the teacher. However, only two reflections mention that the "campaign" mentioned by the teacher affects the pupils motivationally. Only one student explained that the campaign taught the children that the problem was already being solved worldwide and that they could actively engage in concrete actions. In her explanation, the student reasons by theoretical references cited in literature: [27] I also find the reference to the International Biodiversity Day beneficial - children know and see that something is going on with things around them, which they can relate to, where they learn about things, how and where to apply their further interest in the subject.

Students have rightly recognized that the individual's responsibility is linked to a person's personal commitment - to go do something that I am not actually responsible for, but I am responsible for it morally. In essence, they themselves recognized that the responsible conduct demands Jonas's second type of responsibility, which leads a person to what is "to be done" for future generations.

\section{Conclusion}

The topics of education for global citizenship are related to the concept of human responsibility for the whole planet Earth and the future of humanity. It is a different kind of responsibility than that toward which a person is routinely lead in society and at school. This was also shown in the analysis of the teaching lessons by future teachers. Being responsible in global development education means feeling that these subjects touch the very being of man and that they are encouraging him to engage in a particular committed action.

For the teachers, these topics are connected with many challenges. Teachers should realize that our stereotypical thinking, moralizing and formal approach dull the human conscience and are, unfortunately, often present in major topics. This prevents the development of children's moral competence and their understanding of global ethics. The teacher should prepare for situations in which the pupil will feel or experience the relationship of the subject to real life. Real human life is not a taxonomic list of causes and consequences, but is always bound to a specific situation and behavior of a person. Furthermore, the teacher should be a model. If he/she is not internally identified with the subject, it is difficult to lead pupils to personal engagement, as was recognized by students in our research sample. A person's behavior must be consistent with his inner convictions.

\section{Acknowledgment}

The study has been financially supported by project PROGRES Q17 Teacher preparation and teaching profession in the context of science and research, PROGRES Q01 Theology as a way of interpreting history, traditions and contemporary society and by project of IP (Institutional plan of the Catholic Theological Faculty 2016-2018).

\section{References}

[1] In this sense, R. Palous speaks about the topics of ecology - see PALOUS, R.: Homo Educandus: Philosophical Foundation of Education Theory (in Czech). Karolinum, Praha, 2011.

[2] PELCOVA, N.: Philosophical and Pedagogical Anthropology (in Czech). Karolinum, Praha, 2004. - cf. the words of W. GAUDELLI: Educators like me Believe that Teaching the Next Generation to Think of the World Less as a Repository of Resources and a Dump but more as an Inviolable Entity is a Vital Dimension of What it Means to be Educated in the 21st Century. Introduction Global Citizenship Education: Everyday Transcendence. Routledge, New York /London, 2016. 
[3] People who live in a technocratic society "desire to own more and to be successful at all costs." KRALIK, R., JAKOBSEN, T. S.: Kierkegaard's Ethics as an Answer to Human Alienation in Technocratic Society. Communications - Scientific Letters of the University of Zilina, 19(1), 25-29, 2017; see also: KONDRLA, P., REPAR, P.: Ontological Consequences of the Ethics of Technology. Communications - Scientific Letters of the University of Zilina, 19(1), 19-24, 2007; For an incisive analysis (backed by empirical data) of the influence of mass media in a consumerist society in Slovakia see: LESKOVA, A., VALCO, M.: Identity of Adolescents and its Dimensions in the Relation to Mass Media: Philosophical-Ethical Reflections. XLinguae, 10(3), 324-332, 2017.

[4] BRAVENA, N.: "Do Not Be Concerned Just/Only About Yourself...” Transcendence and Its Importance For Socializing And Shaping a Child as a Personality (in Czech). PedF UK, Praha, 2016.

[5] Cf. two concepts of the problem of the authentic being of Kierkegaard and Haring in KONDRLA, P., KRALIK, R.: Authentic Being and Moral Conscience. European Journal of Science and Theology, 12(4), 155-164, 2016.

[6] JONAS, H.: The Imperative of Responsibility (in Czech). Oikoymenh, Praha, 1997.

[7] Ibid.

[8] Ibid.

[9] HELUS, Z.: Turnaround Education Including Its Impacts on Application of Control in Education (in Czech). Paideia: Philosophical e-journal of Charles University, 11(3-4), 1-10, 2014. - Cf. SPILKOVA, V.: Changes in the Primary Education in the Czech Republic (in Czech). Portal, Praha, 48-49, 2005.

[10] HELUS, Z., BRAVENA, N., FRANCLOVA, M.: Perspectives of Teaching Profession (in Czech). PedF UK, Praha, 2012, see also p. 50; 59n. - Cf. the modern concept of the so-called "transcendent anthropology" - the anthropological basis of transcendence and its importance for the value orientation of man, i.e. transcendence as something that "goes beyond the purely personal, individual, self-centered plane of human life, [as something] that expands the boundaries of the human ego (self-boundaries)....". KOLAR, P.: Secularization, Spiritual Care, and Value Survey (in Czech). Theologicka revue, 85(2: 195 - 225), p. 203. 2017. For an incisive treatment of transcendence from the viewpoint of theological anthropology see: VALCO, M.: Kierkegaard's ,Sickness unto Death' as a Resource in our Search for Personal Authenticity. European Journal of Science and Theology, 12(1), 97-105, 2016; VALCO, M.: Chemnitz's Eucharistic Christology as an Impulse for Ecumenical Dialogue between East and West. Konstantinove Listy, 10(2), 141-150. 2017.

[11] FEP BE [online]. Praha, 2017. Available: http://www.nuv.cz/uploads/RVP_ZV_2017_verze_cerven.pdf.

[12] FEP BE. Furthermore, for the older elementary school, the notion of responsibility can be found in the following areas of education: Education for Citizenship (p. 51), man and health (p. 92) and man and the world of work (p.104), dramatic education (p. 114).

[13] FEP BE. 130-134, 135-137, 139.

[14] For more, see the issue of European citizenship, JUROVA, J., LESKOVA, A.: Multicultural Education in the Process of European Citizenship Formation. In. Educating the World Citizen, May 21.-23 2005. The International Conference on Intercultural Communication Competence, USA, 261-274, 2008.

[15] Education for Global Citizenship. A Guide for Schools [online]. Oxfam House, Oxford, 2015. Available: ///C:/Users/dell/ Downloads/Global_Citizenship_Schools_WEB.pdf.

[16] BRAVENA, N.: Nurturing Global Citizenship? (in Czech). Puzzle of the Themes, which are moving the World. Educational Program of Varianty, Teachers Agents of Change. Clovek v tisni, Praha, 11-17, 2015.

[17] Cf. NIGEL, D., WILLIAMS, J.: Global Citizenship: A Critical Introduction. Routlegde New York, Oxford, 2002.

[18] ANDREOTTI, V.: Soft versus Critical Global Citizenship Education. Policy and Practice: A Development [online]. Education Review, 3, 48 - 51, 49, 2006. Available: https://www.developmenteducationreview.com/issue/issue-3/soft-versus-criticalglobal-citizenship-education. - DAVIES, L. Global citizenship: Abstraction or Framework for Action? Educational Review, 58(1), 5-25, 12, 2006.

[19] ROBBINS, M., FRANCIS, L., ELLIOT, E.: Attitudes toward Education for Global Citizenship among Trainee Teachers. Research in Education, 69(1), 93-98, 2003.

[20] STARY, K., DVORAK, D., GREGER, D., DUSCHINSKA, K.: The Professional Development of Teachers: Professional Support for Student Achievement (in Czech). Karolinum, Univerzita Karlova v Praze, Praha, 2012.

[21] Term see for example DAVIES, L.: Global Citizenship: Abstraction or Framework for Action? 5.

[22] Research data has also been used for quantitative comparative analysis, the goal of which is to investigate the pattern of attention and types of reasoning of pre-service teachers studying at one university to be teachers of five different subjects (forthcoming). We also individually and quantitatively focus on the data pertaining to homeland study, or to education for global citizenship (forthcoming). 


\section{kOMNIKCCle}

[23] ULICNA, K., STARA, J., NOVOTNA, M.: Teacher in the Eyes of Future Primary School Teachers. HOUSKA, M., et al. (Eds.): Efficiency and Responsibility in Education. Proceedings of 14th International Conference, Czech Republic, 490-497, 2017.

[24] HRUBES, M., VAVROVA, T.: Stereotypes in the Teaching of Global Developmental Education (in Czech) [online]. The Research Report. Centrum obcanskeho vzdelavani FHS UK, Praha, 2015. Available: http://mkc.cz/doc/Stereotypy_Vyzkumna_zprava. pdf.

[25] From the results of the study, teaching of the historical curriculum in primary schools has proved to be more constructive in terms of experience and in the direction of teaching toward affective goals. The authors point out that one of the most important objectives of primary school education is the mediation and conveying of the importance of key social values, which is also in agreement with the Education Policy Strategy of the Czech Republic 2020 (www.vzdelavani2020.cz), where the educational priorities of education for sustainable development and active citizenship are found. STARA, J., STARY, K.: Study of the History of Education at Elementary Schools. Pedagogical Orientation, 27(1), 6-29, 27, 2017. Available: https://journals.muni.cz/pedor/ article/view/6736.

[26] STARA, J.: Upbringing of Thinking in European and Global contexts (in Czech). Narodni institut pro dalsi vzdelavani, Praha, 19, 2016.

[27] Ibid. 